
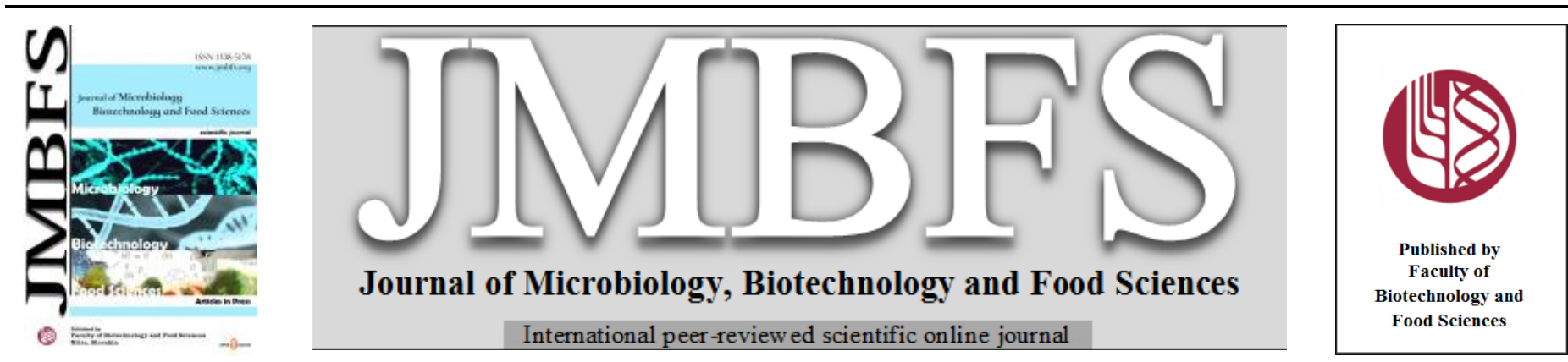

\title{
ANTIVIRAL AND ANTI-QUORUM SENSING ACTIVTIES OF LYOPHILIZED AQUEOUS EXTRACT OF PROPOLIS FROM SÉTIF
}

\author{
Samia Mezaache-Aichourl, Abdelhalim Khenchouche², Nora Haichourl, Aziza Kharchi' ${ }^{1}$,Amel Khellil ${ }^{1}$, Elkhamsa Soltani ${ }^{2}$, Hamid \\ Melouli $^{3}$, FMI Natrah ${ }^{4}$ and Mohamed Mihoub Zerroug ${ }^{1,5 *}$
}

$\operatorname{Address(es):~}$

${ }^{1}$ Laboratoire de Microbiologie Appliquée, Faculté des Sciences de la Nature et de la Vie, Université Ferhat Abbas Sétif 1, 19000 Sétif, Algérie. Tel. $21336620140 /$ 213774065878.

${ }^{2}$ Laboratoire de Biochimie Appliquée, Faculté des Sciences de la Nature et de la Vie, Université Ferhat Abbas Sétif 1, 19000 Sétif, Algérie.

${ }^{3}$ Laboratoire d'oncogénèse virale, Institut Pasteur d'Algérie, Alger, Algérie.

${ }^{4}$ Laboratory of Natural products, Department of Aquaculture, Faculty of Agriculture, University Putra Malaysia, 43400 UPM, Selangor, Malaysia.

${ }^{5}$ Département de Microbiologie et de Biochimie, Faculté des Sciences de la Nature et de la Vie, Université Batna 2, Algérie.

*Corresponding author: med.zerroug@gmail.com

https://doi.org/10.55251/jmbfs.5222

\section{ARTICLE INFO}

Received 27. 8. 2021

Revised 6. 12. 2021

Accepted 8. 12. 2021

Published 1. 4. 2022

Regular article OPEN $\partial_{\text {AcCESS }}$

\begin{abstract}
Aqueous extracts are preferentially used in traditional medicine in Algeria. Among these extracts, propolis is used for the treatment of wounds, boils, canker sores, burns. The purpose of this study was to evaluate the antiviral/antiquorum sensing (anti-QS) characteristics of Propolis aqueous extract collected from bee hive near Sétif (east of Algeria) against human pathogenic viruses and gram negative bacteria. First the Maximal Allowable Concentration (MAC) of the lyophilized aqueous extract of propolis was determined to avoid the toxicity of the extract. A human lymphoid cell line that contains Epstein Barr Virus (EBV) genome as an episome (P3HR-1) and HEp-2 infected with Coxsackievirus (CVB4), were selected according to their ability to deliver endemic infectious viruses at high titers. Antibacterial activity was screened by evaluating anti-QS capacity of the extract. Pre-treatment revealed that the MAC of the extract reduces the viral titer of Coxsackievirus by half a $\log$ from $\mathrm{TCID}_{50}=10^{5.07}$ to $\mathrm{TCID}_{50}=10^{4.6}$, and protected HEp-2 against CVB4 infection. While no antiviral effect on the EBV replication was obtained. The anti-QS capability of the extract was showed against Chromobacterium violaceum strain 026, and by protecting Artemia from Vibrio harveyi BB120 infection.The aqueous extract pre-treatment has not antiviral protection, for DNA viruses. It protected HEp-2 cells against CVB4 infection, degraded Acyl Homoserines lactones (AHL), and protected animal Artemia.
\end{abstract}

Keywords: lyophilized aqueous extract; propolis; anti-QS; antiviral; cytotoxicity

\section{INTRODUCTION}

In big cities like Algiers, there are herbalists essentially at the level of the markets, and their stalls are frequented by a broad public which goes from the adept diligent, convinced of the benefits of the alternative medicines, to the indigent patient in search of an accessible treatment (Hammiche et al., 2013). Hive products have been used by humans for millennia. Beehive products such as honey, propolis, and royal jelly were extensively used to treat several diseases (Pasupuleti et al., 2017). Propolis is still the most used one in folk medicine worldwide. It is collected from sap flows, bark, and leaf buds of a considerable variety of plants, ranging from annual plants to perennial ones. However, the most plants visited for such collection are poplar and conifer trees (Nadjafi et al., 2007). Recent studies revealed a new type that was named Mediterranean Propolis, which contains high levels of diterpenoids. This propolis was collected from Greece (Popova et al., 2010; Celemli et al., 2013), Malta (Popova et al., 2011), Turkey (Silici et al., 2007; Duran et al., 2011), Algeria (Piccinelli et al., 2013; Soltani et al., 2017; Chaa et al., 2021). Bees use propolis as an immunity component that protects their community from micro and macroorganisms' invasion. The propolis is gifted by its anti putrefaction activity against animal corpses. Rufatto et al. (2017) confirmed that propolis has many activities, antimicrobial, anticancer, and antioxidant activities. These activities are directly related to; its chemical components, the variability of flora and harvest time, bee species as well as the processing technique (Calegari et al., 2017; Rufatto et al., 2017). During the two last decades, several studies have explored the capabilities of the aqueous extract of propolis. These reported several activities as; antitumor either against malignant transformation by retroviruses (Huleihel and Ishano, 2001) or inhibition of malignant cell lines (Nadjafi et al., 2007), antioxidant (Gülçin et al., 2010), immunomodulatory (Orsatti et al., 2010; Soltani et al., 2017), protective against Ultraviolet A (Butnariu and Giuchici, 2011), antiviral (Bufalo et al., 2009), anticariogenic (Oršolić et al., 2003) and antimicrobial (Domacoski et al., 2010;
Monte et al., 2014; Soltani et al., 2017, 2021). Plant extracts may have activities that inhibit bacterial virulence and pathogenicity. These effects are neither bactericidal nor bacteriostatic and do not put pressure to develop resistance (Chenia, 2013)

In an editorial Williams (2006) reported that virulence factors constitute one of a variety of bacterial physiological processes regulated via "Quorum Sensing", Antimicrobial chemotherapy aimed at inhibiting the regulation of virulence factor expression could have a more global effect on the ability of an organism to establish infection (Alksne and Projan, 2000). Powerful antipathogenic compounds able to target bacterial signaling systems are present in nature. These compounds (Hentzer and Givskov, 2003) such as Cinnamaldehyde (Brackman et al., 2011) interfere directly with Quorum sensing (QS) signaling systems that control biofilm formation, pathogenicity, and virulence, which brings an attractive target for developing drugs that control microbial activity (Hentzer and Givskov, 2003). In the present study two goals were targeted: (i) The first goal evaluated the cytotoxic/protective power of the lyophilized aqueous extract of Propolis in the presence and absence of virus or bacteria; and (ii) the second goal focused on the investigation of an eventual mode of activity of the extract: its anti quorum sensing (anti-QS) power.

\section{MATERIAL AND METHODS}

\section{Material}

Propolis

The raw propolis was harvested by scraping the hive honeycombs on a site (El Guasria) adjacent to the central campus of the Ferhat Abbas University Sétif 1 between August and September 2012. 


\section{Bacterial Strain}

Chromobacterium violaceum strain 026, Vibrio harveyi BB120, and Artemia cysts were from the laboratory of Dr. Natrah FMI Faculty of Agriculture, University Putra Malaysia.

\section{Cell lines and viruses}

Human lymphoid cell line (P3HR-1 cells) that contains Epstein Barr Virus (EBV) genome as an episome,HEp-2 cells derived from human squamous cell carcinoma of the larynx and Coxsackievirus (CVB4); have been provided respectively by Viral Oncogenesis Laboratory and the referenced Enterovirus Laboratory for the Coxsackievirus (Pasteur Institute of Algiers, Algeria). The CVB4 virus was propagated in HEp-2 cells in Eagles Minimum Medium (EMEM) enriched with $2 \%$ fetal calf serum (FCS) and stored at $-80^{\circ} \mathrm{C}$

\section{Methods}

\section{Lyophilized Aqueous Extract}

The lyophilized aqueous extract of propolis was obtained as previously described by Haichour et al. (2021). Extracts solutions were prepared by dissolving 100 $\mathrm{mg} / \mathrm{mL}$ of the lyophilized powder obtained in sterile water, filtered through Millipore millex syringe driven filter unit $(0.22 \mu \mathrm{m})$. Then a serial dilution $(1 / 2$ and $1 / 4$ ) of each solution is made for the anti-QS, and for antiviral activity, $25 \mathrm{mg} / \mathrm{mL}$ were used in a serial dilution by half till $7.81 \mu \mathrm{g} / \mathrm{mL}$.

\section{Cell culture}

Cells of P3HR-1, were cultivated at a rate of $5.10^{5}$ cells $/ \mathrm{mL}$ in Roswell Park Memorial Institute (RPMI1640) medium supplemented with 10\% FCS from Welgene (Hinuma et al., 1967), $1 \%$ of antibiotic (Penicillin-streptomycin; SigmaAldrich $®$ ), and $1 \%$ of the L-Glutamine (Sigma-Aldrich $®$ ); incubated at $37^{\circ} \mathrm{C}$ with $95 \%$ of humidity and $5 \% \mathrm{CO}_{2}$ (Zur Hausen et al., 1979)

Cells of HEp-2 were cultivated in Hank Minimum Essential Medium (HMEM) supplemented with $10 \%$ FCS, $1 \%$ L-Glutamine, and $100 \mu \mathrm{U} / \mathrm{mL}$ of Penicillin and $100 \mu \mathrm{U} / \mathrm{mL}$ of Gentamicin (Sigma-Aldrich ${ }^{\circledR}$ ) (Gorphe, 2019).

\section{Cytotoxicity test of the extract}

Cytotoxicity of the extracts was performed according to Abid et al. (2012) with some modifications, instead of MTT (3-[4,5- dimethylthiazol-2-yl]-2,5-diphenyl tetrazolium bromide) crystal purple for HEp2 and trypan blue for P3HR-1 cell which were reduced by viable cells (Strober, 2015) and. The viability of the cells was evaluated spectrophotometrically at $492 \mathrm{~nm}$ by the Crystal Purple $(0.5 \%)$ staining method for HEp2 (Ait-Mbarek et al., 2007), and Trypan blue method for P3HR-1(Strober, 2015). Cell suspensions $\left(5 \times 10^{5}\right.$ cells $\left./ \mathrm{mL}\right)$ were distributed $(100$ $\mu \mathrm{L} /$ well) and cultivated as described in cell culture section using 96-well plates, and after incubation at $37^{\circ} \mathrm{C}$ for $24 \mathrm{~h}$ they were treated with $50 \mu \mathrm{L}$ of the extract at different concentrations, the cells were incubated for an additional time of $48 \mathrm{~h}$ (Abid et al., 2012). The blank consist of wells receiving cells without treatment. The cytotoxicity percentage in HEp2 was calculated as [(U - T) / U] x 100, where $\mathrm{U}$ and T were respectively the OD492 of untreated and of treated cells. The $50 \%$ cytotoxic concentration (CC50) calculated by regression analysis was defined as the compound's concentration $(\mathrm{mg} / \mathrm{mL})$ required for the reduction of cell viability by $50 \%$. While for P3HR-1 cells the percentage of cell viability (Vi) was performed by inverse microscopy enumeration using the following formula (Anonymous, 2006): Vi \%= number of Clear cells/Total Cells number X 100

\section{Viruses' inhibition assays}

Confluent HEp-2 cells in microplates, were treated with decreasing concentrations of the extract from the MAC (Maximal Allowable Concentration: nontoxic) between $0.78 \mathrm{mg} / \mathrm{mL}$ and $0.09 \mathrm{mg} / \mathrm{mL}$. After 2 hours of incubation; $100 \mu 1$ TCID $_{50}$ (Tissue Culture Infectious Dose at 50\%) of the viral suspension were added and incubated for 48 hours at $37^{\circ} \mathrm{C}$ under $5 \% \mathrm{CO}_{2}$. Viral inhibition effect (cell viability) and cytopathological change were assessed using values of Crystal violet absorbance at $492 \mathrm{~nm}$ after 24 and $48 \mathrm{~h}$. Inhibitory concentration $50 \%$ ( $\left.\mathrm{IC}_{50}\right)$ corresponds to the concentration which decreases by $50 \%$ the cytopathic effect of the virus $(50 \%$ cellular protection). The protection percentage was calculated according to the following formula:

Percent protection $=[($ ODT $) \mathrm{V}-(\mathrm{ODC}) \mathrm{V}] /[(\mathrm{ODC}) \mathrm{M}-(\mathrm{ODC}) \mathrm{V}] \times 100$. Where (ODT) $\mathrm{V}$, (ODC) $\mathrm{V}$, and (ODC) $\mathrm{M}$ indicate respectively; absorbance of the treatment, the virus-infected control, and mock-infected control (Abid $\boldsymbol{e t}$ al. 2012).

Cells of P3HR-1 were cultivated as in the precedent test, the Falcon flasks were incubated for $3 \mathrm{~h}$ at $37^{\circ} \mathrm{C}$. In each Falcon flask except the cell control, TPA (Tetradecanoyl-phorbol-13-acetate) was added at a final concentration of 20ng / $\mathrm{mL}$ (TPA is dissolved in Dimethyl Sulfoxide (DMSO) at one $\mathrm{mg} / \mathrm{mL}$ ). Then flasks were incubated for $72 \mathrm{~h}$ as previous conditions. Antiviral activity was performed by Trypan blue method or by Indirect Immune Fluorescence (IFI) (Strober, 2015)

\section{Screening the anti-QS}

Chromobacterium violaceum strain 026 (CV026) was grown in Luria Bertani broth (LB) with $20 \mu \mathrm{g} / \mathrm{mL}$ Kanamycin (SIGMA) and $5 \mu \mathrm{g} / \mathrm{mL}$ of N-Hexanoyl-DLHomoserine Lactone (SIGMA) for $48 \mathrm{~h}$ at a temperature of $32^{\circ} \mathrm{C}$ with $140 \mathrm{rpm}$ aerobically to an estimated concentration of $10^{9}$ cell $/ \mathrm{mL}$. $20 \mathrm{~mL}$ of CV026 were mixed with $80 \mathrm{~mL}$ soft LB Agar (0.8\%, SIGMA) and homogenized. The mixture was poured onto hard Agar $(1.5 \%)$ to have a double layer, after its solidification wells were made in the upper layer using a sterile Pasteur pipette. $20 \mu \mathrm{L}$ of the prepared extract of each dilution was filled in the prepared well. Negative controls consist of distilled water; the positive control was Trans-cinnamaldehyde (SIGMA Aldrich) at $0.1 \mathrm{M}$. Plates were incubated overnight at $32^{\circ} \mathrm{C}, \mathrm{CV} 026$ was used to detect and respond to the presence of Acyl Homoserines lactones (AHL) molecules through the synthesis of purple pigmentation (violacein), absence of the purple color indicated inhibition of violacein and degradation of AHL molecules (degradation of QS activity). The diameters of the non pigmented observed zones were measured (Noorashikin et al., 2016). To confirm the degradation of AHL another assay was performed as follows.

\section{AHL degradation assay}

For this purpose, $10 \mu \mathrm{g} / \mathrm{mL}$ of N-Hexanoyl-DL-Homoserine Lactone (HHL, $8 \mu \mathrm{l} / 2 \mathrm{~mL}$ ) were added to the positive control as well as the extract solution. This later was filtered through a $22 \mu \mathrm{m}$ filter and then $10 \mu \mathrm{L}$ were spotted on the LB agar plate already inoculated with $100 \mu \mathrm{L}$ of CV026. The last step was repeated after 4 hours (Noorashikin et al., 2016). The QS degradation activity was observed through violacein inhibition, and the diameters of the non pigmented observed zones were measured.

\section{Artemia Challenge}

Artemia was used for testing the toxicity of the extract on living organisms, according to Soto-Rodriguez et al. (2003) with some modifications. First cysts of Artemia were decapsulated aseptically in sterile seawater to facilitate their hatching. Decapsulated cysts in falcon tubes were placed on aerator with constant light at $28^{\circ} \mathrm{C}$, and incubated for $24 \mathrm{~h}$ at least. Secondly, two batches of Artemia with $12.5 \mu \mathrm{g} / \mathrm{mL}$ of the extract were prepared, one for testing its toxicity and the second for protecting Artemia against $V$. harveyi BB120 $\left(10^{6} \mathrm{cell} / \mathrm{mL}\right)$; in addition to the control batches consisting of Artemia (i) without extract and bacteria (-ve one) (ii) and without extract but with bacteria (+ve one). The batches consist of $20 \mathrm{~mL}$ of sterile seawater to which $100 \mu \mathrm{L}$ of yeast extract $(10 \mathrm{~g} / \mathrm{L})$ and twenty hatching Artemia were added. The experiment was repeated two times with two repetitions.

\section{Statistical analysis}

Data were analyzed using Graph Pad Prism 8.4.2 Statistical software (Graph Pad Software, USA). Analysis of Variance (ANOVA), one way and Tukey's (anti Qs, Hep2 protection); two way and Tukey's (Artemia viability, P3HR-1, and Hep 2 cell cytotoxicity), two way and Sidak's multiple comparisons test (AHL degradation). Data were presented as mean \pm standard error (SEM) and differences were considered significant at $P<0.05$.

\section{RESULTS}

\section{Cytotoxicity and antiviral effect of lyophilized aqueous extracts}

The lyophilized aqueous extract of propolis showed a cytotoxic effect on the viability of tested cells (HEp-2, fig. 1 and P3HR1, fig. 2) with a CC 50 at $7 \mathrm{mg} / \mathrm{mL}$ for HEp-2 cells and $0.230 \mathrm{mg} / \mathrm{mL}$ for P3HR1 cells.

While concentrations of $0.78,0.39$, and $0.19 \mathrm{mg} / \mathrm{mL}$; showed no inhibition effect on HEp-2 cells ( $100 \%$ of the cells are viable); the same was observed with P3HR1 at concentrations bellow $125 \mu \mathrm{g} / \mathrm{mL}$. Concentrations of $25,12.5,6.25,3.12,1.56$ $\mathrm{mg} / \mathrm{mL}$, and $500,250 \mu \mathrm{g} / \mathrm{mL}$ acted respectively on the growth and appearance of HEp-2 and P3HR1 cells with different inhibition percentages compared to untreated control. A concentration of $25 \mathrm{mg} / \mathrm{mL}$ inhibited $60 \%$ of HEp- 2 cells; at $12.5,6.25,3.12$, and $1.56 \mathrm{mg} / \mathrm{mL}$, the inhibition percentage was respectively about 54, 49, 40 and $28 \%$ as shown by the Purple Crystal method; and P3HR1 cells were inhibited at a rate of $67.96 \%$ when treated with $500 \mu \mathrm{g} / \mathrm{mL}$ shown by Trypan blue method.

By evaluating its antiviral effect and compared to positive control, the MAC of the extract reduces the viral titer of Coxsackievirus by half a $\log$ from TCID $_{50}=10^{5.07}$ to $\mathrm{TCID}_{50}=10^{4.6}$. Concerning EBV and after induction of P3HR1cells by TPA, the results obtained showed no antiviral effect on the replication of the virus, the expression of the Viral Capsid Antigens (VCA) by IFI was very significant.

Otherwise, the aqueous extract of propolis showed a protective effect against CVB4 infection (fig.3), it inhibited the multiplication of the virus in HEp-2 cells with an $\mathrm{IC}_{50}$ of $0.53 \mathrm{mg} / \mathrm{mL}$ and a selective (therapeutic) index (SI) of 13.20. A 
total destruction of the cellular layer was obtained with concentrations of 0.19 , $0.09,0.04,0.02,0.01$ and $0.006 \mathrm{mg} / \mathrm{mL}$; while concentrations of 0.78 and 0.39 $\mathrm{mg} / \mathrm{mL}$ showed a protective effect against CVB4 infection, with protection percentages of $76 \%$ and $37 \%$ respectively.

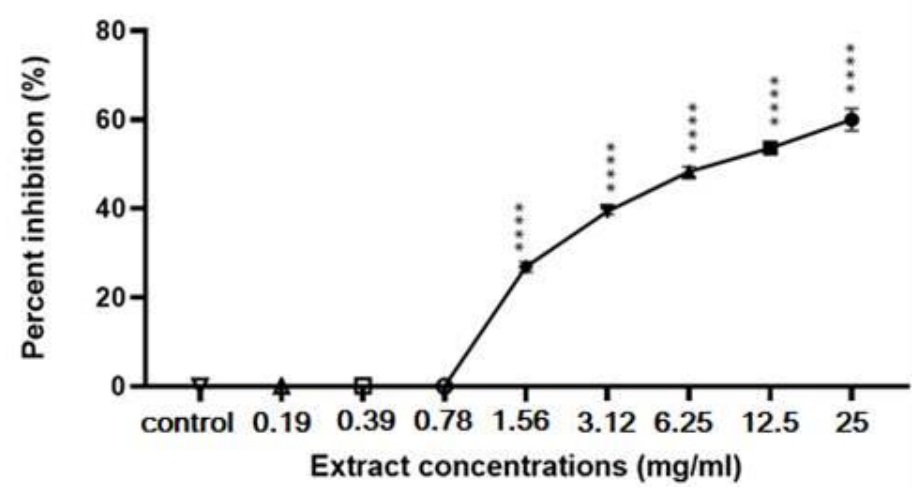

Figure 1 Cytotoxicity of the lyophilized aqueous extract of Propolis on Hep2 cells ****: Statistically very significant $(\mathrm{P}<0.0001)$

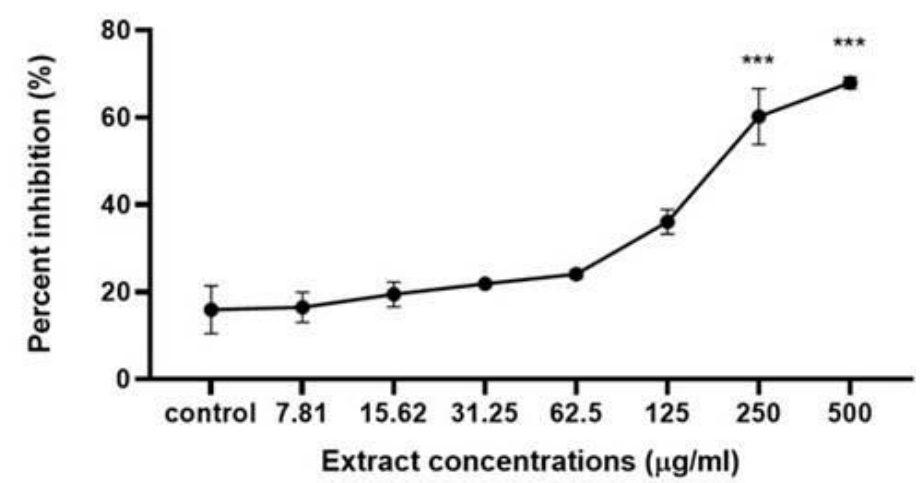

Figure 2 Cytotoxicity of the lyophilized aqueous extract of Propolis on P3HR1 cells. $* * *$ Statistically significant $(\mathrm{P}<0.0004)$

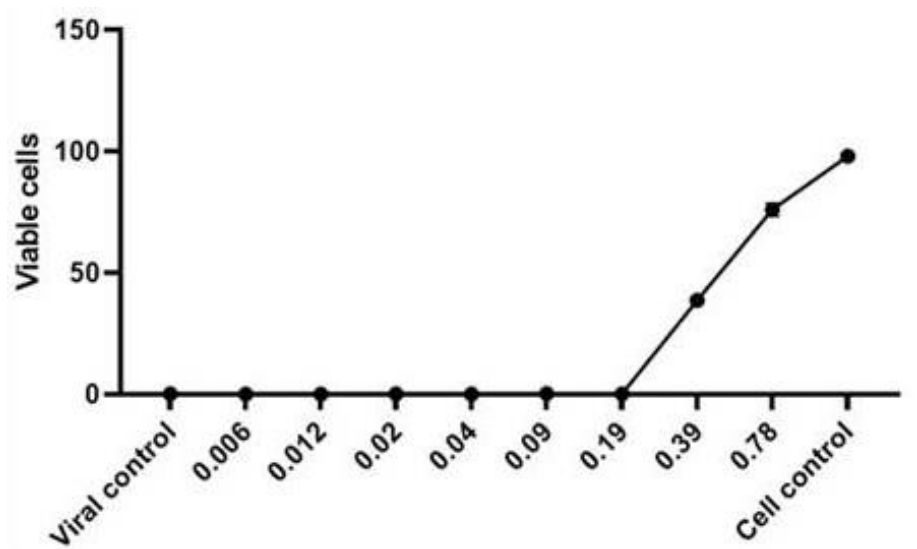

Figure 3 Protection of Hep2 cells against infection by CVB4

Antibacterial activity versus Anti-QS activity

\section{Artemia Challenge}

In the in vivo virulence test Artemia survived differently when it was infected with Vibrio harveyi $\mathrm{BB} 120$ in the presence and absence of the extract; amongst twenty Artemia used in the first batch $19 \pm 1$ were still alive, they were grown and moved well after $24 \mathrm{~h}$ of feeding. While in the second batch treated with propolis extract and inoculated with $V$. harveyi $\mathrm{BB} 120,77.6 \%$ of the organisms were still alive and being well after $24 \mathrm{~h}$ of feeding too. On the other hand, the positive control with $V$. harveyi $\mathrm{BB} 120$ decreased to $12 \pm 1$ organisms ( $60 \%$ alive) after $6 \mathrm{~h}$ of treatment only (fig. 4).

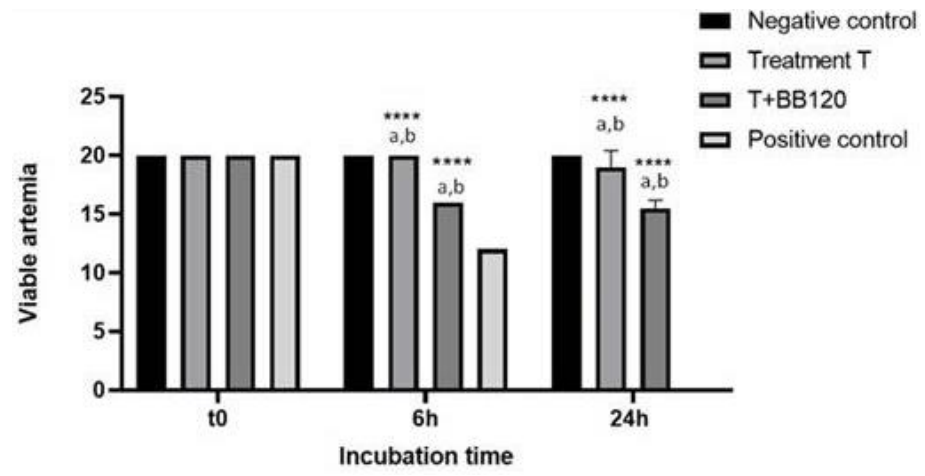

Figure 4 Protection of Artemia against infection by Vibrio harveyi BB120 Negative control: Neither treatment nor BB120; T: treatment with aqueous extract at $12.5 \mu \mathrm{g} / \mathrm{mL} ; \mathrm{T}+\mathrm{BB} 120$ : treatment with aqueous extract at $12.5 \mu \mathrm{g} / \mathrm{mLl}+$ Vibrio harveyi $\mathrm{BB} 120$ at $10^{6} \mathrm{cell} / \mathrm{mL}$; positive control: Vibrio harveyi $\mathrm{BB} 120$ at $10^{6} \mathrm{cell} / \mathrm{mL}$; ****: Statistically very significant $(\mathrm{P}<0.0001)$

\section{Anti-QS activity of the lyophilized aqueous extract}

To understand partially how the extract protected Artemia against $V$. harveyi BB120, its anti-QS capacity was evaluated. As compared to a positive control consisting of Cinnamaldehyde, the inhibition, by the extract, of QS was demonstrated by the loss of the purple pigment in strain 026 of Chromobacterium violaceum, thus showing a clear zone around the wells and the diameter of which was concentration-dependent. The negative control was only water which remained purple (fig. 5, 6).

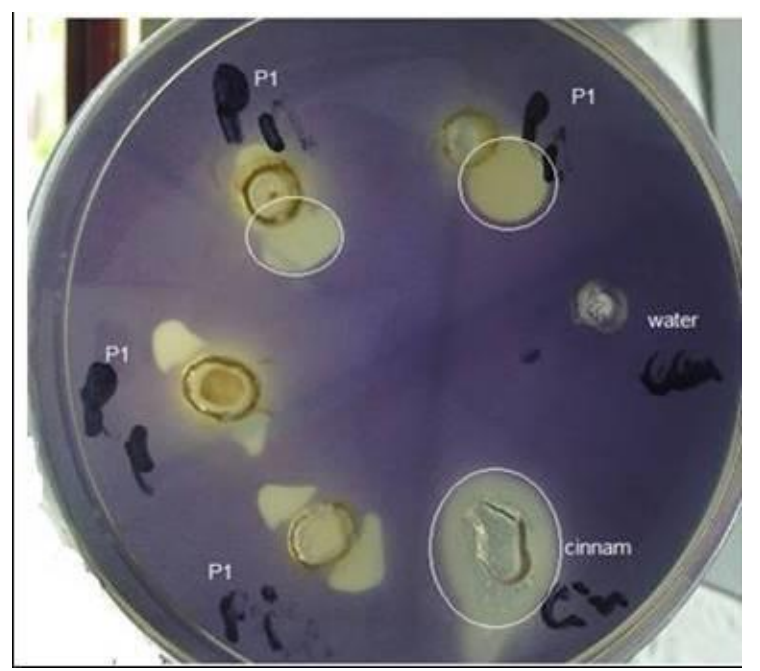

Figure 5 AntiQuorum Sensing screening

P1: lyophilized aqueous extract of propolis at $100 \mathrm{mg} / \mathrm{mL}$, water: negative control, cinnam: positive control (cinnamaldehyde at $0.1 \mathrm{M}$ )

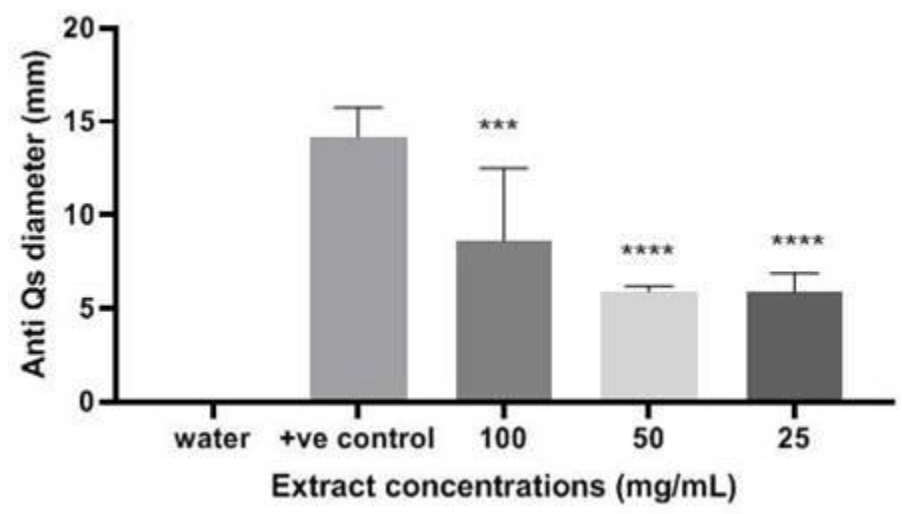

Figure 6 AntiQuorum Sensing activity of Propolis lyophilized aqueous extract 100, 50 and 25mg: aqueous extract of propolis diluted $/ \mathrm{ml}$, water: negative control cinnam: positive control (cinnamaldehyde at $0.1 \mathrm{M}$ ); Anti-Qs diameter: diameter of the degradation zone of the quorum sensing compound produced by Chromobacterium violaceum strain 026 . ****: Statistically very significant $(\mathrm{P}<0.0001), * * *$ : Statistically significant $(\mathrm{P}<0.0004)$ 


\section{Degradation of QS molecules}

The degradation power of the extract (fig.7) was confirmed using the agar diffusion method, by the absence of pigmentation (inhibition of the violacein purple color regulated by QS) in the inoculated zone. This latter was increased after $72 \mathrm{~h}$ (fig.8) as compared to positive and negative controls. The extract inhibited the pigmentation with mean a diameter of $12.05 \pm 1.11 \mathrm{~mm}$, while the positive control inhibited with a mean diameter of $14.20 \pm 1.42 \mathrm{~mm}$.

The statistical analysis revealed that no significant differences were obtained for all the antiviral tests, while a significant difference was obtained for AHL degradation one.

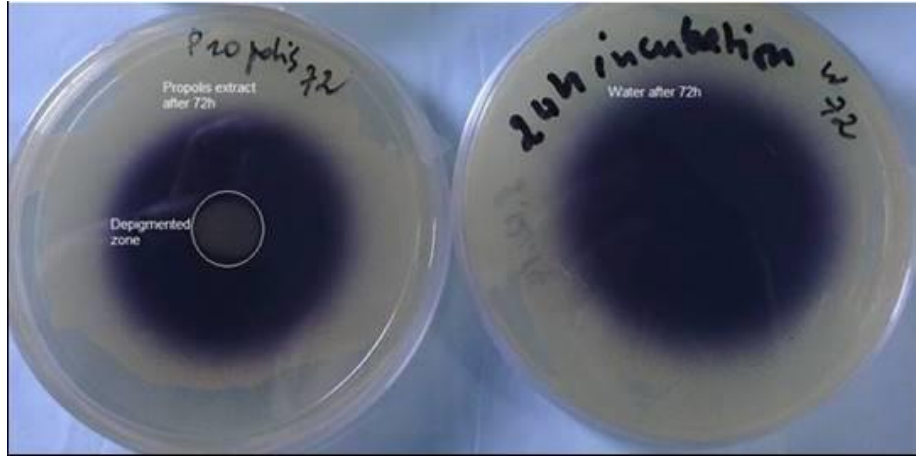

Figure 7 Degradation of Acyl Homoserine Lactone by lyophilized aqueous extract of Propolis

On the left: degradation zone (depigmentation) after $72 \mathrm{~h}$ of incubation, on the right: negative control inoculated with water after $72 \mathrm{~h}$.

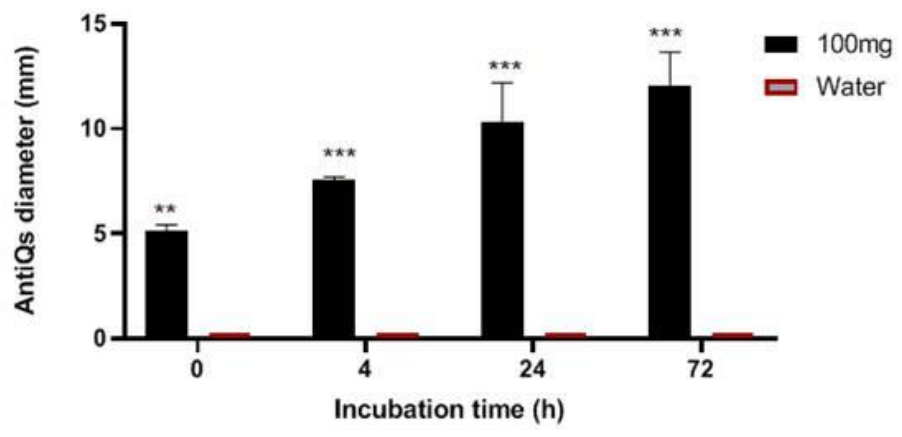

Figure 8 Gradually increasing of the degradation zone

Anti-Qs diameter: diameter of the degradation zone of the quorum sensing compound (Acyl homoserine lactone); $* * *$ : Statistically significant $(\mathrm{P}<0.001)$, ** Statistically less significant $(\mathrm{P}<0.002)$

\section{DISCUSSION}

In Algerian traditional medicine, plant preparations are most often aqueous and sometimes based on olive oil. That's why the purpose of this study was to test cytotoxic activity of the lyophilized aqueous extract and secondly determining its effectiveness against pathogens.

In the present study, the lyophilized aqueous extract of propolis showed a cytotoxic effect on the growth of HEp-2 and P3HR1cell lines, where 54\% of the HEp-2 cell were inhibited by $12.5 \mathrm{mg} / \mathrm{mL}$, and $50 \%$ of the P3HR1 cells were inhibited by 190 $\mu \mathrm{g} / \mathrm{mL}$. Similar results were obtained by Nadjafi et al. (2007), while there are differences in the propolis extract concentrations, the propolis extracts were toxic to McCoy, BHK21, HEp-2, and HeLa; with inhibition up to $75 \%$ of HEp-2 cells at a concentration of $2 \mathrm{mg} / \mathrm{mL}$. They reported that treatment of the cells by aqueous extract of propolis acted as antiproliferative cells, it helps to kill the proliferative cells and stimulate normal cells multiplication during the treatment. In contrast, in another study, there was no effect of the lyophilized propolis aqueous extract on cell viability (similar to the mock) of head-kidney leucocytes from gilthead seabream (Sparus aurata L.) when it was used at 100 and $200 \mu \mathrm{g} / \mathrm{mL}$ (Soltani $\boldsymbol{e}$ al., 2017).

On the other hand at non cytotoxic concentrations, the extract inhibited Coxsackievirus (CVB4) replication in HEp 2 cells and protected them against CVB4 infection, while VCA was expressed in P3HR1 cells; before or simultaneously to virus infection. Bufalo et al. (2009) demonstrated that the bes antiviral activity against poliovirus (PV1) replicated in HEp-2 cells was obtained in the simultaneous administration of propolis, as the same time the vira quantification was relatively lower. The propolis extract tested would have partially blocked the penetration and entry of viral particles into the cytoplasm of infected cells; this step is necessary for the virus to continue its replication (Huleihel and Ishano, 2001; Bufalo et al., 2009), or lead to RNA degradation before the virus entry into cells or after their release to the supernatant (Bufalo et al., 2009).

In addition to the cytotoxic effect against the growth of lineage cells (HEp-2 and P3HR1), the expression of surface antigens (VCA) of the EBV rather than the proteins involved in tumor genesis would be attributable to an anti-proliferative effect. Pretreatment and continuous treatment of propolis extract in NIH/3T3 cell cultures showed an impressive inhibition of malignant cell transformation by Moloney murine Sarcoma Virus (MuSV) (Huleihel and Ishano, 2001).

The antiviral and the anti proliferative activities of the extract of propolis could be attributed to its contents in flavonoids $(3,047 \pm 0,004 \mathrm{mg} / \mathrm{g})$, polyphenols $(221 \pm$ $0,001 \mathrm{mg} / \mathrm{g}$ ), and its four identified derivatives of cinnamic acid (Soltani, 2017; Soltani et al., 2021)

Cinnamaldehyde a derivative of cinnamic acid has been reported as an inducer of apoptosis on various cancer cell lines in vitro, that transduced the apoptotic signal via reactive oxygen species (ROS) generation (Ka et al., 2003; Li et al., 2016). Investigating flavonoids from plant extracts against Coxsackievirus B3 (CVB3), Abid et al. (2012) demonstrated that flavonoids enhanced antiviral activity at noncytotoxic concentrations. While earlier, Bufalo et al. (2009) demonstrated that cinnamic acid a compound from propolis has also an antiviral activity against replication of PV1. Hazam et al. (2017) demonstrated that direct contact with acyclovir and other pure molecules e.g. quercetin, caffeic acid and chlorogenic acid were very effective in inhibiting Herpes simplex 1 virus ( HSV1) and varicella zoster virus (VZV) while in the case of adenovirus type 5 (ADV5) most of substances were not so efficient. The propolis aqueous extract was most effective in pre-treatment of ADV5 - infected cells, more efficient than the propolis tincture, as well as more efficient than acyclovir; while post-treatment it did not protect HSV1 infected cells (Hazam et al., 2017). These findings may explain partially the non activity of the lyophilized aqueous extract on EBV (DNA virus) and vice versa.

The inhibition of cell growth, necrosis, apoptosis (Oršolić et al., 2001, 2003), and metastasis formation (Oršolić and Bašić, 2003, 2005a) in tumor cells are the main mechanisms by which propolis acted. Metastasis is mediated by immunomodulatory activity by increasing macrophages activity (Oršolić and Bašić, 2003).

Using continuous and discontinuous drug exposure methods on P3HR1cell lines in an unpublished data, Rihane and Ouanes (2017) showed a dose dependent apoptotic effect and DNA fragmentation of the lyophilized aqueous extract of propolis tested in the present study. The anti metastatic activity as well as its antitumor activity (Oršolić $\boldsymbol{e t}$ al., 2005), were the result of synergistic activities of a water-soluble derivative of propolis (WSDP) components (Oršolić and Bašić, 2005b) as flavonoid e.g. caffeic acid a cinnamic acid derivate (Oršolić et al., 2001) and polyphenolic compounds (Oršolić et al., 2003).

The lyophilized aqueous extract of propolis protected Artemia against bacterial infection and inhibited the QS activity. This extract has proved bactericidal activities against several bacteria; Vibrio harveyi, Photobacterium damselae (Soltani et al., 2017), Staphylococcus aureus ATCC25923, Bacillus cereus ATCC10876, Pseudomonas aeruginosa ATCC27853, Klebsiella pneumoniae ATCC700603 and Enterobacter cloacae (Soltani et al., 2021), respectively two marine opportunistic (Soltani et al., 2017) and human pathogenic bacteria (Soltani et al., 2021). The lowest bactericidal activity was found against $P$. damselae (Soltani et al., 2017), P. aeruginosa ATCC27853, Klebsiella pneumoniae ATCC700603 and Enterobacter cloacae (Soltani et al., 2021); while the highest was in the case of $V$. harveyi (Soltani et al., 2017) Staphylococcus aureus ATCC25923 and Bacillus cereus ATCC10876 (Soltani et al., 2021). Monte et al. (2014) have already demonstrated that ferulic acid (hydroxycinnamic acid) was more effective than gallic acid (hydroxybenzoic acid) against Escherichia coli and Staphloccocus aureus.

In the presence of Vibrio harveyi BB120, with and without the addition of the extract Artemia survives differently. The extract significantly increased the survival of Artemia after infection. Earlier, Brackman et al. (2011) reported the increased survival of Caenorhabditis elegans nematodes infected with $V$. harveyi, $V$. anguillarum and $V$. vulnificus in the presence of cinnamic acid and its structural analogs.

These activities can be assigned to its components as, benzoic acid, cinnamate, and its derivatives which were present in the extract (Soltani et al., 2017). Cinnamic acid derivative, cinnamaldehyde, and most analogs reduced the Vibrio species starvation response, affected biofilm formation in $V$. anguillarum, $V$. vulnificus, and $V$. cholera, protease production in $V$. anguillarum and $V$. cholera, and pigment production in $V$. anguillarum. They blocked at least AI-2 (autoinducer-2) QS (Brackman et al., 2011).

Our data showed decreased violacein production when the extract was added exogenously, as observed through halo zone formation, as obtained by Kalia et al. (2015). As expected, zones of QS inhibition were also observed with the control cinnamaldehyde. This latter has been reported as HSL degrader (Noorashikin $\boldsymbol{e t}$ al., 2016).

Finally, the aqueous propolis extract, had antiviral activity against CVB 4, do not provide antiviral protection in the case of EBV, and had an anti-QS activity which correlated with the QSI (quorum sensing inhibition) activity that disrupts QS AHL bacterial communication mechanism. On the base of these results, more investigations are needed for the study of the Algerian propolis extract. 


\section{CONCLUSION}

The use of natural compounds to attenuate viral and bacterial pathogenicity is an attractive approach, particularly if, at the dosages used these inhibitors are nontoxic for living organisms. In this study, the aqueous extract of propolis from Sétif possess anti viral activity against B4 Coxsackievirus and an anti-QS effect in $C$. violaceum. The use of the extract as quorum sensing-disrupting compound protects living organisms as Artemia larvae from $V$. harveyi BB120 without a negative effect on the growth of the larvae.

Acknowledgements Authors would like to thank the Ministry of Higher Education and Scientific Research of Algeria and the Directorate General for Scientific Research and Technological Development (DGRSDT) for the financial assistance. Project reference D01N01UN190120190003

\section{REFERENCES}

Abid, B.N., Rouis, Z., Lassoued, M.A., Sfar, S., Aouni, M., (2012). Assessment of the cytotoxic effect and in vitro evaluation of the anti-enteroviral activities of plants rich in flavonoids. J. App. Pharma. Sci. 02 (05), 74-78. doi: $10.7324 / \mathrm{JAPS} .2012 .2532$

Ait-Mbarek, L., Ait-Mouse, H., Elabbadi, N., Bensalah, M., Gamouh, A., Aboufatima, R. \& Benharref, A. (2007). Chait, Anti-tumor properties of blackseed (Nigella sativa L) extracts. Braz. J. Med. Biol. Res. 40, 839-847. https://doi.org/10.1590/S0100-879X2006005000108.

Alksne, L.E. \& Projan, S.J. (2000). Bacterial virulence as a target for antimicrobial chemotherapy. Curr. Opin. Biotechnol. 11, 625-636.

doi: $\underline{\text { 10.1016/s0958-1669(00)00155-5 }}$

Brackman, G., Celen, S., Hillaert, U., Van Calenbergh, S., Cos, P., Maes, L., Nelis H.J. \& Coenye, T. (2011). Structure-Activity Relationship of Cinnamaldehyde Analogs as Inhibitors of AI-2 Based Quorum Sensing and Their Effect on $\begin{array}{llll}\text { Virulence of Vibrio spp. PLoS ONE. 6(1), e16084 } & \end{array}$ https://doi:10.1371/journal.pone.0016084

Bufalo, M.C., Figueiredo, A.S., Sousa, J.P.B., Candeias, J.M.G., Bastos, J.K. \& Sforcin, J. M. (2009). Anti-poliovirus activity of Baccharis dracunculifolia and propolis by cell viability determination and real-time PCR. J. App. Microbiol. 107, 1669-1680. https://doi.org/10.1111/j.1365-2672.2009.04354.x

Butnariu, M.V. \& Giuchici, C.V. (2011). The use of some nano emulsions based on aqueous propolis and lycopene extract in the skin's protective mechanisms against UVA radiation. J. Nano. Biotechnol. 9, 3. http://www.jnanobiotechnology.com/content/9/1/3.

Calegari, M.A., Prasniewski, A., Da Silva, C., Sado, R.Y., Maia, F.M.C., Tonial, L.M.S. \& Oldoni, T.L.C. (2017). Propolis from Southwest of Parana produced by selected bees: Influence of seasonality and food supplementation on antioxidan activity and phenolic profile. Ann. Braz. Acad. Sci. 1-12. http://dx.doi.org/10.1590/0001-3765201620160499.

Celemli, O.G., Hatjina, F., Charistos, L., Schiesser, A. \& Ozkirim, A. (2013). More insight into the chemical composition of Greek propolis; differences and similarities with Turkish propolis. Z Naturforsch C. 68 (11-12), 429-438. https://doi:10.5560/znc.2013.68c0429

Chaa, S., Boufadi, M. Y., Keddari S. \& Benchaib, A. H. (2021). Protective effect of propolis from Tigzirt on epirubicin-induced cardiotoxicity and nephrotoxicity. Journal of Pharmacy \& Pharmacognosy Research, 9 (4), 549-562. http://jppres.com/jppres

Chenia, H.Y. (2013). Anti-Quorum Sensing Potential of Crude Kigelia africana Fruit Extracts. Sensors. 13, 2802-2817. doi: 10.3390/s130302802

Domacoski, P.B.B., de Baurab, V.A. \& Funayama, S. (2010). Antibacterial Activity of Aqueous Extract of Appis mellifera Propolis from the City of Ibaiti, PR. UNOPAR. Cient. Ciênc. Biol. Saúde. 12(4), 33-36 https://journalhealthscience.pgsskroton.com.br/article/view/1282/1227

Duran, N., Muz, M., Culha, G.\& Ozer, B. (2011). GC-MS analysis and ant leishmanial activities of two Turkish propolis types. Parasitol. Res. 108 (1), 95105. https://doi.org/10.1007/s00436-010-2039-Z

Gorphe, P. (2019). A comprehensive review of Hep-2 cell line in translationa research for laryngeal cancer. A J Cancer Res. 9(4), 644-649. PMID: 31105993; PMCID: PMC6511639

Gülçin, I., Bursal, E., Sehitoglu, M.H., Bilsel, M. \& Gören, C.A. (2010) Polyphenol contents and antioxidant activity of lyophilized aqueous extract of propolis from Erzurum, Turkey. Food Chem. Toxicol 48, 2227-2238 doi: $10.1016 /$ j.fct.2010.05.053

Haichour , N., Mezaache-Aichour, S., Khenchouche, A., Melouli, H., Natrah F.M.I. \& Zerroug, M. M.(2021). Antiviral, Antibacterial and Anti-Quorum Sensing Activities of a Lyophilized Aqueous Pine Resin Extract. Phytothérapie, https://doi.org/10.3166/phyto-2021-0283

Hammiche, V., Merad, R. \& Azzouz, M. (2013). Plantes toxiques à usage médicinal du pourtour méditerranéen, In: Springer Paris Berlin Heidelberg New York (Eds.), Phytothérapie Pratique. (C) Springer-Verlag France, Paris, pp. 17-18. French. https://link.springer.com/book/10.1007/978-2-8178-0375-3

Hazem, A., Pitică-Aldea, I.M., Popescu, C., Matei, L., Dragu, D., Economescu, M., Alexiu , I., Crișan, I., Diaconu, C.C., Bleotu, C. \& Lupuliasa, D. (2017). The antiviral/virucidal effects of alchoolic and aqueous extracts with propolis Farmacia, 65(6), 868-876. http://www.revistafarmacia.ro/issue62017.html

Hentzer, M. \& Givskov, M. (2003). Pharmacological inhibition of quorum sensing for the treatment of chronic bacterial infections. J. Clin. Inves. 112 (9), 1300-1307. https://doi:10.1172/JCI200320074

Hinuma, Y., Konn, M., Yamaguchi, J. \& Grace Jr. J.T. (1967). Replication of herpes-type virus in a Burkitt lymphoma cell line. J. Virology. 1(6), 1203-1206. doi: 10.1128/JVI.1.6.1203-1206.1967

Huleihel, M. \& Ishano, V. (2001). Effect of propolis extract on malignant cell transformation by moloney murine sarcoma virus. Arch. Virol. 146, 1517-1526. https://doi.org/10.1007/s007050170075

Ka, H., Park, H-J., Jung, H-J., Choi, J-W., Chod, K-S., Had, J. \& Lee, K-T. (2003). Cinnamaldehyde induces apoptosis by ROS-mediated mitochondrial permeability transition in human promyelocytic leukemia HL-60 cells. Cancer Lett. 196, 143 152. https://doi: 10.1016/s0304-3835(03)00238-6

Kalia, M., Yadav, V.K., Singh, P.K., Sharma, D., Pandey, H., Narvi, S.S. \& Agarwal, V. (2015). Effect of Cinnamon Oil on Quorum Sensing Controlled Virulence Factors and Biofilm Formation in Pseudomonas aeruginosa, PLoS ONE. 10 (8), e0135495. https://doi: 10.1371/journal.pone.0135495

Li, J., Teng, Y., Liu, S., Wang, Z., Chen, Y., Zhang, Y., Xi, S., Xu, S., Wang, R. \& Zou, X. (2016). Cinnamaldehyde affects the biological behavior of human colorectal cancer cells and induces apoptosis via inhibition of the PI3K/Akt signaling pathway. Oncology Rep. 35, 1501-1510. https://doi.org/10.3892/or.2015.4493

Monte, J., Abreu, A.C., Borges, A., Chaves Simões, L. \& Simões, M. (2014) Antimicrobial Activity of Selected Phytochemicals against Escherichia coli and Staphylococcus aureus and Their Biofilms. Pathogens. 3, 473-498. https://doi:10.3390/pathogens3020473

Nadjafi, M.F., Vahedy, F., Seyyedid, M., Jomehzedeh, R. \& Bozary, K. (2007) Effect of the water extracts of propolis on stimulation and inhibition of different cells. Cytotechnol. 54, 49-56. https://doi:10.1007/s10616-007-9067-2

Noorashikin, M.N., Li, L.Y., Karim, M., Daud, H.M. \& Natrah, F.M.I. (2016). Screening and identification of quorum sensing degraders from live feed Artemia. $\begin{array}{llll}\text { J. } & \text { Environ } & \text { Biol. } & \text { 87, }\end{array}$ http://www.jeb.co.in/journal_issues/201607_jul16_spl/paper_21.pdf

Orsatti, C.L., Missima, F., Pagliarone, A.C., Bachiega, T. F., Búfalo, M .C. J. \& Araújo Jr. P., Sforcin, J. M. (2010). Propolis Immunomodulatory Action In Vivo on Toll-Like Receptors 2 and 4 Expression and on Pro-Inflammatory Cytokines Production in Mice. Phytother. Res. 24, 1141 1146. https://doi.org/10.1002/ptr.3086

Oršolić, N. \& Bašić, I. (2003). Immunomodulation by water-soluble derivative of propolis: a factor of antitumor reactivity. J. Ethnopharmacol. 84, 265-273. https://doi:10.1016/s0378-8741(02)00329-x

Oršolić, N. \& Bašić, I. (2005a). Antitumor, hematostimulative and radioprotective action of water-soluble derivative of propolis (WSDP). Biomed. Pharmacother 59, 561-570. https://doi.org/10.1016/j.biopha.2005.03.013

Oršolić, N. \& Bašić, I. (2005b). Water-soluble derivative of propolis and its polyphenolic compounds enhance tumoricidal activity of macrophages. $J$ Ethnopharmacol. 102, 37-45. https://doi: 10.1016/j.jep.2005.05.036

Oršolić, N. Horvat, A. \& Bašić, I. (2001). A comparison of antitumor activity of propolis and its related flavonoids. Proceedings of the $37^{\text {th }}$ International Apicultural Congress, 28 October - 1 November 2001, Durban, South Africa APIMONDIA. $\quad 1-8 . \quad$ ISBN: $0-620-27768-8$ https://pdfs.semanticscholar.org/7721/a1cdc09636f767d4d1f6c1f417c45b56fc05. pdf

Oršolić, N., Kosalec, I. \& Bašić, I. (2005). Synergystic Antitumor Effect of Polyphenolic Components of Water Soluble Derivative of Propolis against Ehrlich Ascites Tumour. Biol. Pharm. Bull. 28(4), 694-700. https://doi: 10.1248/bpb.28.694

Oršolić, N., Sver, L., Terzic, S., Tadic, Z. \& Bašić, I. (2003). Inhibitory effect of water-soluble derivative of propolis and its polyphenolic compounds on tumor growth and metastasizing ability: a possible mode of antitumor action. Nut. Cancer, 47(2), 156-163. https://doi.org/10.1207/s15327914nc4702_8

Pasupuleti, V. R., Sammugam, L., Ramesh, N. \& Gan, S.H., (2017). Honey, Propolis, and Royal Jelly: A Comprehensive Review of Their Biological Actions and Health Benefits. Oxid. Med. Cel. Longev. 1-21. Article ID 1259510 , https://doi.org/10.1155/2017/1259510.

Piccinelli, A.L., Mencherini, T. \& Celano, R. (2013). Chemical composition and antioxidant activity of Algerian propolis. J. Agricul. Food Chem. 61 (21), 50805088. https://doi.org/10.1021/jf400779w

Popova, M., Trusheva, B. \& Antonova, D. (2011). The specific chemical profile of Mediterranean propolis from Malta. Food Chem. 126 (3), 1431-1435 https://doi:10.1016/j.foodchem.2010.11.130

Popova, M.P., Graikou, K., Chinou, I. \& Bankova, V.S. (2010). GC/MS profiling of diterpene compounds in mediterranean propolis from Greece. J. Agricul. Food. Chem. 58 (5), 3167-3176. https://doi.org/10.1021/jf903841k

Rihane, R. \& Ounas, F.N. (2017). Antiproliferative effects of some flavonoids, vitamins and plant extracts on the growth of the P3HR1 lymphoblastoid line. Master's thesis Department of Microbiology, SNV Faculty, UFA Sétif 1 Algeria. $78 \mathrm{p}$, French 
Rufatto, L.C., Dos Santos, D.A., Marinho, F., Henriques, J.A.P., Roesch Ely, M. \& Moura, S. (2017). Red propolis: Chemical composition and pharmacological activity. Asian Pacific J. Trop. Biomed. 7(7), 591-598. https://doi.org/10.1016/j.apjtb.2017.06.009

Silici, S., Unlu, M. \& Vardar-Unlu, G. (2007). Antibacterial activity and phytochemical evidence for the plant origin of Turkish propolis from different regions. W. J. Microbiol. Biotechnol. 23 (12), 1797-1803. https://doi: 10.1007/s11274-007-9430-7

Soltani, E. (2017). PhD Thesis. Caractérisation et activités biologiques de substances naturelles, cas de la propolis. Département de Génie des Procédés. Faculté de Technologie. UFA Sétif 1, Algeria. pp. 165, French. https://pdfs.semanticscholar.org/27a0/f284ac516d148d949190ae64df04c9f5cd5c. pdf

Soltani, E., Cerezuela, R., Charef, N., Mezaache-Aichour, S., Esteban, M.A. \& Zerroug, M.M., (2017). Algerian propolis extracts: Chemical composition, bactericidal activity and in vitro effects on gilthead Seabream innate immune $\begin{array}{llll}\text { responses. } & \text { Fish. } & \text { Shellfi. } & \text { Immunol. }\end{array}$ https://doi.org/10.1016/j.fsi.2017.01.009

Soltani, E.K., Zaim, K., Mokhnache, K., Haichour, N., Mezaache-Aichour S. Charef N. \& Zerroug M.M. (2021). Polyphenol Contents, Antioxidant and Antibacterial Activities of Aqueous Algerian Propolis Extracts. Phytothérapie, https://doi.org/10.3166/phyto-2021-0282

Soto-Rodriguez, S. A., Roque, A., Lizarraga-Partida, M.L., Guerra-Flores, A. L. \& Gomez-Gil, B. (2003). Virulence of luminous vibrios to Artemia franciscana nauplii. Dis. Aquat. Org. 53, 231-240. doi: 10.3354/dao053231

Strober, W. (2015). Trypan blue exclusion test of cell viability. Curr Protoc Immunol A.3B.1-A.3B.2. https://doi.org/10.1002/0471142735.ima03bs111

Williams, P. (2006). Quorum sensing EDITORIAL. Int. J. Med. Microbiol. 296 57-59. https://doi.org/10.1016/j.ijmm.2006.01.034

Zur Hausen, H., Bornkamm, G.W., Schmidt, R. \& Hecker, E. (1979).Tumor initiators and promoters in the induction of Epstein-Barr virus. Proc Natl Acad Sci U S A, 76(2), 782-785. https://doi.org/10.1073/pnas.76.2.782 